\title{
Designing institutional platforms and arenas for interactive political leadership
}

Sørensen, Eva; Torfing, Jacob

Published in:

Public Management Review (Print)

DOI:

10.1080/14719037.2018.1559342

Publication date:

2019

Document Version

Peer reviewed version

Citation for published version (APA):

Sørensen, E., \& Torfing, J. (2019). Designing institutional platforms and arenas for interactive political leadership. Public Management Review (Print), 21(10), 1443-1463.

https://doi.org/10.1080/14719037.2018.1559342

\section{General rights}

Copyright and moral rights for the publications made accessible in the public portal are retained by the authors and/or other copyright owners and it is a condition of accessing publications that users recognise and abide by the legal requirements associated with these rights.

- Users may download and print one copy of any publication from the public portal for the purpose of private study or research.

- You may not further distribute the material or use it for any profit-making activity or commercial gain.

- You may freely distribute the URL identifying the publication in the public portal.

Take down policy

If you believe that this document breaches copyright please contact rucforsk@kb.dk providing details, and we will remove access to the work immediately and investigate your claim. 


\section{Designing Institutional Platforms and Arenas for Interactive Political Leadership}

\section{Eva Sørensen and Jacob Torfing}

\section{Towards an interactive political leadership?}

We are living in turbulent times characterized by the pervasiveness of wicked problems (Ansell, Trondal and $\varnothing$ gård, 2017) and the proliferation of policy deadlocks and government failures (Light, 2015) that have led to a widespread decline in trust in government (OECD, 2013). In Europe, the refugee crisis, climate change, lifestyle diseases, the ageing of populations, and soaring youth unemployment clearly demonstrate the need for political leaders to orchestrate of collaborative policy innovation processes. Complex societal problems cannot be solved either by recycling standard solutions, or by increasing public expenditure, but require the development of innovative policy solutions. This predicament is prompting elected politicians to move away from managerial and custodial policymaking and towards the leadership of disruptive and risk-prone policy processes based on collaboration with a broad range of societal actors (Ansell and Torfing, 2017).

While societal turbulence is propelling elected politicians to initiate, direct and participate in processes of collaborative policy innovation, the conditions for exercising political leadership in our increasingly polarized, mediatized and fragmented Western societies are deteriorating (Stoker, 2006; Helms, 2012a). Moreover, the traditional perception of democratic political leaders as sovereign decision-makers, who govern society and the economy on behalf of the people through distant, insulated, unilateral policy decisions, is out of sync with reality. As evidenced by the rise of cross-boundary collaboration in networks and partnerships and the growth of new forms participatory democracy, public governance is gradually becoming more interactive (Torfing et al., 2012) and citizens are becoming more assertive (Dalton and Welzel, 2014) and are increasingly seeking to manage the complexities of politics without taking their cues from political parties (Dalton, 2007). Interestingly, the rise of interactive governance and the proliferation of assertive citizens seem to foster a more interactive kind of political leadership in which elected politicians explore and define policy problems, design innovative policy solutions and generate support for their implementation through a carefully orchestrated dialogue with relevant and affected actors such as citizens, civil society actors, interest organizations and private firms (Tucker, 1995; Sørensen, 2018). The development of new forms of interactive political leadership can enhance the overall capacity for producing innovative solutions to the complex policy problems confronting Western societies and may, moreover, help to restore trust in government. However, the ability to spur interactive political leadership is predicated on the design and use of institutional platforms and arenas that combine representative democracy with elements of participatory and deliberative democracy (Bryson and Crosby, 2005). As such, we propose that the future development of interactive forms of political leadership that aim to spur collaborative policy innovation is conditional upon a new type generative governance (Ansell and Gash, 2017) that facilitates sustained interaction between citizens and their political representatives.

This paper creates a rapprochement between the established field of political leadership theory and new theories of collaborative governance and participatory democracy in order to make way for the concept of interactive political leadership. It explores how the institutional design of platforms and arenas can support the development of interactive political leadership that may spur the development of new and bold policy 
solutions through cross-boundary collaboration. The theoretical framework underpinning this argument is first presented and then illustrated through an empirical study of a pioneering attempt to enhance interactive political leadership through institutional reform of political working conditions for local councilors in a Danish municipality. The local rather than national focus is deliberate. Although national parliaments are also being reformed (Beetham, 2011), local governments appear to be more engaged in institutional design experiments (Smith, 2009), perhaps because they are not bound by strict constitutional regulations.

The paper is structured in the following way. First, we discuss the current challenges to political leadership and the prospect for developing a new form of political leadership that is more attuned to the rise of interactive governance and the proliferation of assertive citizens. A review of recent literature leads to the formulation of a theoretical framework for studying interactive political leadership. Next, we explain the procedure for our case selection and the strategy and methods for our data collection and analysis. We then report the empirical findings, before going on to reflect on the favorable conditions for the relatively positive Danish experiences with enhancing interactive political leadership. The conclusion summarizes the key findings and suggests avenues for further research.

\section{Political leadership in the world of interactive governance and assertive citizens}

The current conditions for exercising democratic political leadership are rather unfavorable, resulting in frequent instances of weak leadership and poor governance (Helms, 2012b). Democratic political leadership is increasingly challenged by: 1) the fragmentation and polarization of European populations along crisscrossing socio-economic and post-materialist cleavages (Lijphart, 1999); 2) the surge in democratic disenchantment evidenced by a widespread decline in voter turnout and party membership (Norris, 2011); 3 ) the rise of anti-politics where citizens roundly turn their backs on the way that politics is conducted by selfserving politicians through mediatized mudslinging and voter-catching stunts (Stoker, 2006); and 4) the formation of a multi-level governance system in which old and new state powers are shifted upwards to inter- and supranational institutions, downwards to local governments and outwards to cross-border regions and non-majoritarian institutions (Jessop, 2002; Hooghe and Marks, 2002). Hence, elected politicians face a complex world of distributed and multi-level governance in which the attempt to rally fragmented, disenchanted and resentful citizens behind bold policy reforms appears to be a 'mission impossible'.

While the conditions for governing Western societies are deteriorating, the theory and practice of political leadership has remained surprisingly stable. Politicians continue to be locked into parliamentary committee work (Strøm, 1998), technocratic policymaking (Page, 2012) and blame games played out in the mediatized drama-democracy (Hood, 2011; Helms, 2012a; Klijn, 2014). The prevailing political leadership practices are supported by the underlying conception of politicians as 'elected kings' whom - once the people have bestowed a democratic mandate upon them - have the power to make sovereign decisions and delegate policy implementation to bureaucratic agencies (Olsen, 1978). Hence, classical leadership theory portrays elected politicians as omnipotent decision makers and voters as passive, allegiant followers with little interest in, or capacity for, contributing to public governance (Hamilton et al., 1966 [1787]; Weber, 2009 [1948]).

Today, this image of government is challenged by the rise of interactive forms of governance prompted by the growing fragmentation and complexity of Western societies (Torfing et al., 2012) and the emergence of 
an assertive citizenry in the wake of the educational and anti-authoritarian revolutions from the 1960s onwards (Dalton and Welzel, 2014). The proliferation of governance networks means that an increasing number of political decisions are made in horizontal arenas of cross-boundary collaboration in which relevant and affected actors strive to constructively manage their differences in order to find joint solutions to common problems (Gray, 1989; Kickert, Klijn and Koppenjan, 1997; Sørensen and Torfing, 2007). At the same time, citizens want to be more directly involved in shaping their living conditions than current forms of liberal representative democracy permit (Norris, 2011). This new, active and assertive citizen does not match the old image of voters as passive and allegiant followers (Dalton and Welzel, 2014). Today's citizens are critical, empowered and committed to active engagement in the decisions that affect their lives (Nye, 2008).

This paper argues that the rise of networked forms of governance and the emergence of a new type of critical and assertive followers provides a favorable condition for the development of a new type of interactive political leadership. In contrast to the classical form of sovereign political leadership, interactive political leadership prompts elected politicians to engage a broad range of relevant and affected actors in processes of collaborative interaction through which policy problems are described and defined, and new and bold solutions are designed and endorsed. As such, the concept of interactive political leadership builds on the idea that elected politicians' performance of the core functions of political leadership (Tucker, 1995) will be more enlightened, qualified and robust if they interact with their followers through a sustained dialogue that facilitates knowledge sharing, mutual learning, resource pooling and development of democratic ownership.

Against this background, it is unfortunate that elected politicians are often excluded from policy and governance networks that could help them to better understand the policy problems at hand and to develop and implement innovative, yet feasible, policy solutions (Richardson, 2000; Ansell and Torfing, 2017). Likewise, it is regrettable that politicians' attempts to engage assertive citizens are often confined to hearings and consultations that, because they often take place towards the end of the policy process, leave citizens with no other choice than to oppose and criticize the proposed policies. Hence, there is an urgent need for new guidance on how to develop the theory and practice of political leadership in ways that are more attuned to the rise of interactive forms of governance and the proliferation of a new type of active, competent and critical followers.

This endeavor has, however, been hindered by the fact that well-established theories of political leadership and the new theories of collaborative governance and participatory democracy have developed in splendid isolation from each other (Helms, 2012b; Sørensen, 2017). Studies of political leadership have taken either a biographical, psychological, historical or institutional perspective (Helms, 2014; Post, 2014; Walter, 2014); thus, few scholars have asked themselves how the urgent need for policy innovation and the surge in interactive and participatory governance may transform the way that political leadership is exercised (Sørensen, 2006; Sørensen and Torfing, 2016a; Ansell and Torfing, 2017). Public administration researchers, for their part, have documented the need to find innovative solutions to wicked problems (Roberts, 2000; Koppenjan and Klijn, 2004) and analyzed how collaborative forms of governance can spur innovation (Ansell and Torfing, 2014; Torfing, 2016). However, few of them have studied the role of political leadership in collaborative governance and innovation processes that tend to decenter the formal institutions of government by linking them with less formal arenas for sustained dialogue (Sørensen, 2006; Koppenjan, Kars and Voort, 2011; Klijn, 2014). To compensate for these oversights, we integrate the two different strands of 
theory in order to explore how new forms of political leadership can exploit the rise of interactive governance and the proliferation of assertive citizens to enhance the creation of innovative policy solutions.

Recent developments in collaborative and participatory governance research and political leadership theory have taken the first step towards integrating the two strands of theory. We will first look at how theories of collaborative governance and participatory democracy approaches the analysis of political leadership and then we will consider how political leadership theory tackles the rise of interactive governance and assertive citizens.

Since the early 1990s, theories of collaborative governance have been on the rise (Ansell and Torfing, 2016). Governance is commonly defined as the process through which social and political actors formulate and achieve common goals (Torfing et al., 2012). Many governance researchers focus on how effective governance is produced in and through cross-boundary collaboration between interdependent actors in networks (Marsh and Rhodes, 1992; Rhodes, 1997; Emerson, Nabatchi and Balogh, 2012). Since governance networks do not always emerge spontaneously when needed, and may give rise to destructive conflicts or undesirable outcomes, interest in network management has grown rapidly (Kickert, Klijn and Koppenjan, 1997; Koppenjan and Klijn, 2004).

Attempts to influence the processes and outcomes of governance networks without reverting too much to hierarchical forms of command and control are referred to as metagovernance (Jessop, 2002; Sørensen and Torfing, 2009; Torfing et al., 2012). Research shows that politicians play a limited role in metagoverning governance networks and that metagovernance is typically left to public managers (Sørensen, 2006), even when politicians are formally in charge (Koppenjan, Kars and Voort, 2011). A crucial factor contributing to the marginalization of politicians is that metagovernance tends to be defined in managerial terms. As such, governance network researchers have failed to recognize that metagovernance involves political decisions that only elected politicians have sufficient democratic legitimacy to make. New research solves this problem by drawing a conceptual distinction between 'political metagovernance' and 'administrative metagovernance' (Sørensen and Torfing, 2016a). Political metagovernance involves political efforts to frame and direct governance networks and endorse their policy recommendations. When properly exercised, this not only makes it possible for elected politicians to lend democratic legitimacy to interactive governance arenas (Sørensen and Torfing, 2005), it also enables them to learn about policy problems, seek inspiration for developing new solutions and generate support for their implementation.

Governance researchers were originally interested in how networks enhance effective and democratic governance (Kickert, Klijn and Koppenjan, 1997; Sørensen and Torfing, 2007). Recently, the scope has been broadened to include the question of how cross-boundary collaboration can enhance public innovation (Bommert, 2010; Sørensen and Torfing, 2011). The new research on public innovation has primarily focused on service innovation, but inspired by the seminal work of Polsby (1984) and Kingdon (1984), there is now renewed interest in policy innovation (Krause, 2011) and in how it can be spurred by collaboration in networks (Hartley, Sørensen and Torfing, 2013; Torfing, 2016). Empirical research has explored who local politicians contact in order to learn about innovative policy solutions (Considine, Lewis and Alexander, 2009).

Researchers in the field of participatory democracy have, at least indirectly, pondered these new conditions for political leadership and the need for change. According to Rosanvallon (2011), citizens increasingly expect political leaders to listen and respond to their experiences, ideas and demands and to justify their political 
decisions in the light of the input they receive. This situation calls for the development of an interactive democracy based on a growing proximity between citizens and political leaders. Proximity is defined in terms of a mutual accessibility, openness and receptiveness. For citizens, growing proximity means that they feel empowered to engage in, and monitor, public policymaking, and for political leaders, it provides a valuable resource for governing society and the economy, especially if they can avoid being captured by strong advocacy groups. A key task for political leaders is, therefore, to build institutional arenas that facilitate the exchange of inputs from citizens and societal actors for political justification of the final policy decisions.

In a similar vein, Fung and Wright (2003) claim that the traditional democratic institutions are ill suited to solving complex problems. The solution is not to reduce democracy, but rather to deepen it by expanding the role of citizens and civil society in public governance. Democracy deepens when it is no longer only a matter of electing a government, but also a question of democratizing governance by connecting citizens and political leaders in creative problem-solving processes. According to Fung and Wright (2003), we are witnessing the gradual development of 'empowered participatory governance'. Governance is becoming participatory because it involves ordinary people in reasoned debates about policy issues, and it is empowered due to the growing governance capacity that emanates from mobilizing active and responsible citizens who can help policymakers to develop the solutions that society needs.

In sum, although recent contributions to understanding how interactive and participatory governance can enhance effective, democratic and innovative policymaking tend to downplay the role of government and elected officials, there is a growing interest in how elected politicians can metagovern networks, and in how their political leadership role and capacity for policy innovation can be strengthened by designing, orchestrating and engaging in collaborative governance arrangements.

Recent contributions to political leadership theory suggest that politicians are seeking to strengthen their political leadership by interacting with their followers (Burns, 2003). A study based on interviews with leading politicians in five Anglophone countries shows that political leaders increasingly respond to their need for information, knowledge and ideas by seeking input from external actors (Lees-Marshment, 2015). What seems to be emerging from the somewhat sporadic contacts initiated by elected politicians is a new model of 'deliberative political leadership' through which politicians solicit inputs from actors inside and outside government, evaluate the quality of those inputs, and integrate new ideas into their deliberations about how to solve policy problems (Lees-Marshment, 2015). Empirical examples of this kind of deliberative political leadership are provided by Sirianni (2009), Caluwaerts and Reuchamps (2015), Hendricks (2013) and Ercan (2014).

Other political leadership scholars suggest that in Western societies the 'hard power' associated with Machiavellian-style political leadership is increasingly being supplemented by the exercise of 'soft power' that seems to fit the chaotic distribution of political power amongst manifold actors (Nye, 2008). In today's shared-power world, nobody is in control, and policy solutions can only be found through multi-actor collaboration, which requires that political leaders use soft rather than hard power in order not to alienate their collaborators. Besides charisma and persuasive skills, political leaders can exercise soft power by mobilizing and empowering their followers and ensuring their independence in order to provide the conditions for a critical dialogue that enhances mutual learning and permits the development and testing of new ideas. Hence, the old idea of 'passive followers' is replaced with a new notion of 'active, independent and critical followers' who can contribute to collaborative policy making (Nye, 2008). 
In much the same way, Kane, Patapan and 't Hart (2009) refer to the development of 'dispersed democratic leadership'. In liberal democracies, public leadership is dispersed throughout society and found in different forms and measures in the political, administrative, judicial, social and economic spheres. The dispersion of public leadership makes it difficult for elected politicians to respond to problems and opportunities because they do not have the power and authority that is required to make binding decisions. Political leadership is exercised amidst a multitude of political competitors, critics and opponents with contradictory ideas and intentions that cannot easily be corralled. Hence, political leaders are forced to collaborate with other public leaders, including those from organizations, movements and communities outside the formal political system.

Helms (2012b) explicitly addresses the question of how political leadership theory can learn from governance theory. There is a growing interest in studying ineffective political leadership where political leaders fail to formulate and achieve a clear set of political goals. However, ineffective leadership is often explained solely in terms of the personal characteristics of political leaders who are portrayed as incompetent, ignorant, rigid and intemperate. This diagnosis overlooks another explanation of ineffective political leadership that is often cited in studies of bad governance: namely, that public policies that lack political support and fail to solve the problems at hand are often a result of policy processes that violate democratic norms pertaining to transparency, participation, inclusion, deliberation, accountability etc. As such, the study of good governance practices may help political leaders to do a better job when it comes to designing policies that work in practice and enjoy widespread support.

Masciulli, Molchanov and Knight (2009) go one step further in viewing the interaction between political leaders and their followers as a process of mutual adaptation and innovation. Political leaders respond to challenges from local and global systems by engaging in discussions with their followers, and this interaction transforms the views and ideas both of leaders and followers and stimulates the creation of innovative solutions. In this innovation process, political leaders rely on their charisma and persuasive powers to drive change and inspire their followers to pursue new goals.

In sum, although the majority of political leadership studies continue to study political leadership without much appreciation of interactive forms of governance or the need to spur policy innovation, some recent contributions have taken on the daunting task of rethinking political leadership in the context of collaborative governance.

All in all, our review of recent contributions to collaborative and participatory governance theory and political leadership research reveals a promising scholarly endeavor to link political leadership with interactive governance and policy innovation based on civic engagement and democratic deliberation. The recurrent argument is that we are facing a series of complex societal problems that call visible political leadership, but that the political leadership capacity of elected politicians is being challenged by societal developments and needs to be enhanced by the advancement of interactive political leadership. Such interactive leadership would bring politicians into close and sustained interaction with affected, competent and assertive citizens and knowledgeable, resourceful and critical stakeholders who can help them to better understand the problems at hand and inspire them to develop innovative and yet feasible solutions.

There are several hints in the literature about the need for institutional designs that facilitate sustained dialogue between elected politicians and relevant and affected societal actors. Interactive political leadership 
does not emerge by itself, but requires the construction and institutionalization of physical and/or digital platforms that can facilitate the emergence and multiplication of arenas for interactive policymaking (Crosby and Bryson, 2005). Platforms are defined as generic institutional opportunity structures containing dedicated competences, resources, templates and routines that facilitate the formation, proliferation and adaptation of arenas, which are defined as temporary, rule-bound network structures supporting deliberative interaction between interdependent actors aiming to establish a common ground for creative problem solving and joint decision making (Gray, 1989; Crosby and Bryson, 2005; Ansell and Gash, 2017).

The focus on the institutional design of platforms and arenas for interactive political leadership and collaborative policy innovation introduces a new kind of 'generative governance' (Ansell and Gash, 2017) that breaks with the old idea that public leaders and employees are solely responsible for formulating and implementing public policies. Instead of governing society and the economy through a hierarchical chain of delegation and control, the public sector must construct generative platforms and collaborative arenas that facilitate the co-creation of public solutions (Torfing, 2018). The form and functioning of these institutional platforms and arenas, their role in political decisionmaking, and the way they are linked to the formal institutions of government depend on contextual factors such as political culture and traditions, constitutional and legal rules, and recent experiences with collaborative policymaking. Figure 1 presents the underlying theoretical framework for studying the relations between context, interactive political leadership and policy innovation.

\section{Figure 1 about here}

Figure 1 shows how the context-dependent exercise of interactive political leadership hinges on the coexistence and dynamic coupling of formal political institutions (including the elected assembly and the standing committees) with platforms that enable the formation and adjustment of temporary arenas for interactive policy making. The platforms are designed by the politicians who wants to find new generic ways of facilitating policy interaction with relevant and affected actors. The generic platforms are generative mechanisms that condition and structure the construction, multiplication and adaptation of collaborative arenas that allow elected politicians to engage in sustained dialogue with citizens and stakeholders with a view to producing innovative policy solutions. The deliberative policymaking that takes place in the collaborative arenas may be framed by the politicians who will also tend to play a crucial role in amending and endorsing the innovative policy solutions produced by the collaborative arenas.

Interactive political leadership involves platform construction, arena formation and authoritative decisionmaking in and through formal political institutions as well as sustained interaction with critical and assertive followers in and through collaborative arenas. Hence, when exercising interactive political leadership, politicians must combine elements of collaboration, joint exploration and mutual learning (horizontal interaction) with elements of agenda setting, persuasion, and the narration of political goals, visions and commitments (vertical interaction). The notion of political metagovernance advanced by Sørensen and Torfing (2016a) seems to captures the essence of interactive political leadership. Elected politicians lead by designing, orchestrating, managing and participating in networked arenas that aim to 
produce well-informed and inspiring policy recommendations with a broad-based ownership. As such, interactive political leadership not only involves more interaction, but also more leadership in the sense that politicians should not only lead their voters, their party and their political coalition, but also lead multi-actor arenas that bring together a diverse set of actors in problem-focused and structured deliberations that aim to develop innovative solutions that appeal both to the participants and the representative assembly.

\section{Studying interactive political leadership in practice}

In order to envisage what interactive political leadership might look like in practice, we studied an attempt by the Danish municipality of Gentofte to strengthen local political leadership through the creation of a generic institutional platform and specific temporary arenas for collaborative policy innovation. The POLECOproject used a Delphi study involving expert academics and practitioners and media-based crowd-sourcing to identify 24 municipalities that had recently reformed their democratic political institutions and Gentofte Municipality emerged as the ultimate frontrunner in terms of facilitating interactive political leadership.

Gentofte Municipality has 75,000 inhabitants and is situated north of Copenhagen. It is an affluent, wellmanaged and innovative municipality led by the long-term mayor, Hans Toft, whose Conservative party commands an absolute majority but has nonetheless formed a broad political coalition comprising socialdemocratic and liberal parties. After several years of experimentation with citizen engagement, the City Council discussed the need for an institutional reform of political working conditions in March 2014. A year later, the mayor and the new municipal director called a meeting in the Economic Committee in order to discuss a concrete model for enhancing the political leadership of the local councilors through closer interaction with local citizens and stakeholders. The new model was debated, amended and finally approved by an overwhelming majority in the City Council with effect from the $1^{\text {st }}$ of August 2015. A description of the model was incorporated in the Local Governance Ordinance that regulates the political work of the City Council.

In Denmark, local councilors share legislative and executive powers with the mayor, who is appointed by a majority vote right after the election. The mayor has special responsibility for monitoring the administration's implementation of political decisions, but the elected councilors spend a lot of time in Standing Committees where they prepare council decisions and oversee their implementation. This time-consuming committee work tends to turn elected politicians into relatively insulated, sector-specific 'administrators' suffering from tunnel vision (Kjær and Opstrup, 2016). To counteract this unfortunate tendency, the goal of the institutional reform was to enhance local councilors' involvement in cross-boundary policy development while facilitating a closer dialogue with citizens and societal actors (City Council, 2015). This goal was to be achieved without increasing the local councilors' time consumption, since given that their political work takes place in their free time and they are already overburdened with council work, they have little time to spare for new tasks.

The new institutional design transformed the operation of the City Council and its Standings Committees and introduced a new kind of open and thematic ad hoc committees called Task Committees (Sørensen and Torfing, 2015). The new institutional framework governing the formation of Task Committees provides a platform for establishing problem-specific arenas that facilitate collaboration between social and political 
actors. In the first round, the City Council formed eight Task Committees, ${ }^{1}$ typically consisting of five councilors and ten appointed citizens, who are assisted by three to four administrators acting as facilitators and advisors. The City Council issued a written mandate for each Task Committee. The mandate describes the background and nature of the policy problem, the political conditions for solving it (the overall objectives and the existing policies), and the expected delivery (a vision, policy, strategy, action plan, or list of proposals). It also determines the timeframe and defines the 'competence profiles' of the citizen participants. People from stakeholder organizations can participate as single individuals, but not as representatives of their organization. The mandate and a call for citizen participants matching the competence profiles were widely advertised in local newspapers and on different websites. In the call for participants, citizens were urged to register at the municipal website if they were interested in participating in one of the Task Committees and thought they matched one or more of the competence profiles. At a subsequent meeting the local councilors compared the self-registered would-be citizen participants with the competence profiles and formally selected and appointed the citizen participants. The citizens who were not appointed to a Task Committee were offered alternative ways of participating in sub-committees, workshops, camps and public hearings. The City Council also decided which of the local councilors should participate in which Task Committees. The politicians were distributed based on a mathematical model that ensured proportional representation across all Task Committees.

The Task Committees tend to meet for two or three hours at fixed dates over a period of three to six months, although some may work for longer periods. The meetings are chaired by two local councilors appointed by the City Council. The chair and the vice-chair opens and concludes the meeting. The rest of the meeting is facilitated by skilled administrators who aim to get everybody involved in open-ended discussions about the problem at hand and the ways it can be solved. The meetings are relatively informal, external guests are frequently invited, and deliberative techniques are applied to facilitate knowledge-sharing, stimulate discussion and generate new ideas. At the end of the process, the Task Committee presents its results to the City Council, which then makes the final decision about whether to endorse, amend or reject the deliverance and, if necessary, how to finance and implement it. Hence, the interactive policy process begins and ends with the local council.

In order for the councilors to find time to participate in the new Task Committees, the time spend on meetings in the Standing Committees was drastically reduced. The number of meetings was reduced from eleven to four per year, and the role of the Standing Committees was changes so that they no longer were supposed to carry out administrative case processing, but rather strategically monitored the policy programs for which they were responsible in order to identify problems and challenges that either called for new political guidelines or for the formation of a new Task Committee that could formulate a novel policy strategy. In order to facilitate this radical transformation of the Standing Committees, direct responsibility for administrative operations was delegated to the City Council, the Economic Committee and the administration. In addition to suggesting that the City Council form a New Task Committee, the Standing Committees may also provide feedback on the work carried out in relevant Task Committees in order to build a broader ownership base for their final policy recommendations.

\footnotetext{
${ }^{1}$ Soon after, two more Task Committees were added, bringing the total number to 10 . The second round established 13 Task Committees.
} 
The relations between the City Council, the Standing Committees, the Local Governance Ordinance and the Task Committees in the Gentofte Model are depicted in figure 2.

\section{Figure about here}

The new institutional design creates a new division of labor according to which administrators call, organize and facilitate the meetings in the Task Committees; elected politicians focus on policy innovation in areas that call for collective action; citizens co-create public solutions together with politicians; and the responsibility for policy implementation is shared by all three actors. According to the municipal director, the new division of labor 'corrects' an unfortunate role switch in which politicians performed a large number of administrative tasks and administrators were in charge of designing policy solutions that politicians subsequently endorsed without any real political discussion. A survey from Gentofte showed that before the institutional reform, $97 \%$ of all council decisions were passed without any political discussion.

Back in 2014, we had been invited to provide inspiration for Gentofte City Council's reform of its political working conditions. After having lost sight of the actual reform process, we were commissioned to evaluate the new institutional design and make recommendations about how it could be improved. Our close relationship with the municipality raise some ethical questions about impartiality. However, it was agreed in the contract that, although the overall research questions would be discussed with the municipality and the final reports would be checked for factual errors, there would be no municipal interference in our substantial conclusions and recommendations. The potential bias towards confirmation of the intended results of the institutional reform was counteracted by a deliberate search for empirical evidence of potential risks and worries articulated by the local councilors prior to the launch of the reform and by subjecting our preliminary results to peer review performed by Danish colleagues.

Our formative evaluation of the new institutional design builds on mixed methods. Empirical data were collected from September 2015 to May 2016. We gathered relevant documents from the City Council (description of the new design, mandates for the Task Committees, minutes from council meetings in which the input from the Task Committees was discussed), the Standing Committees (agendas and minutes from ordinary meetings) and the Task Committees (agendas and minutes from meetings and events). We observed meetings in the City Council, Standing Committees and Task Committees. We conducted interviews with eight politicians and six public managers before and after the majority of the Task Committees had concluded their work, and we interviewed four citizens from different Task Committees. Informants were selected to achieve maximum variation and the transcripts were coded based on key variable relating to antecedent conditions, formal and informal aspects of the institutional design, political and administrative leadership, collaborative interaction, drivers and barriers for collaborative policymaking, and policy outcomes. Finally, we conducted an online survey with all the politicians, public administrators and citizens/stakeholders that participated in the new Task Committees. A seven-point Likert scale was used to collect responses to evaluative statements concerning participation, process, leadership, drivers and barriers, and outcomes. In constructing the frequency tables, we added together the frequencies for 'completely (dis-)agree', 'strongly (dis-)agree' and '(dis-)agree' to simplify reporting. The response rate in the survey was $94 \%$ for the politicians 
$(n=18), 100 \%$ for the administrators $(n=27)$ and $80 \%$ for the citizens $(n=79)$. The collection of different types of data permitted us to triangulate our findings.

\section{Empirical findings from the study of the Gentofte Model}

In order to assess how interactive political leadership and collaborative policy innovation were enhanced by the new institutional design, we evaluate the functioning, interaction and impact of the Task Committees, the Standing Committees and the City Council (see Sørensen and Torfing, 2016b).

The Task Committees were all relatively well-functioning, except for two which focused on implementation issues rather than policy development. The use of written mandates to frame the process and the appointment and distribution of the members of the Task Committees both worked well. Most politicians agreed that the procedure for selecting citizens had resulted in sufficiently diverse groups of relevant and affected actors. There was good attendance at the meetings, although in some Task Committees it was not unusual that a few citizens were absent. The politicians were keen to participate in the meetings, but councilors who sat on three or more Task Committees claimed that their time budget was more strained than before. However, the time spent by the politicians has been redistributed so that two thirds of the time that was previously spent on case processing in the Standing Committees is now spent on policy development in the Task Committees. The politicians welcomed this shift. One politician remarked that: 'For me it has been very rewarding to participate in the Task Committee for Youth Policy. It is more fun than participating in the Standing Committee meetings because it gives more energy and inspiration. It provides a much better foundation for policy development'. Another politician seconded this: 'It has been extremely positive to work with people from the outside who are really engaged and committed. (...) It is also surprising how easy it has been for all of us to agree on new policy solutions'.

The politicians found it difficult to identify negative aspects of the functioning of the new Task Committees. However, some of them find that the discussions are sometimes a bit slow and unimaginative, leading to policy solutions characterized as 'the least common denominator'. At the same time, the politicians seemed to concur that: 'we cannot get all the new ideas ourselves from inside the City Hal, but need inspiration from external actors'. In addition, some politicians complained that it was 'irritating that the administrative facilitators ran the meetings', but most of them agreed that 'it is good to have someone to drive the process forward who is not politically implicated'. Finally, some politicians reported that it was difficult to find the right balance between listening and posing questions to citizens and stakeholders and expressing their own opinions, ideas and vision. Anxious about dominating, they sometimes went the other way and held back too much, thus abdicating their leadership role.

The citizens felt welcome in the Task Committees and well-informed about their purpose and the political issues they were dealing with. In addition, $90 \%$ of the citizens found that the politicians were responsive to the points that they raised, and $85 \%$ agreed that they had plenty of opportunities to give the politicians critical feedback. With regard to the outcomes, $97 \%$ of the citizens agree that both politicians and citizens have learned a lot about the policy problem and the possible solutions through their participation in the Task Committees and $88 \%$ agree that the collaborative interaction had led to the development of good and 
feasible solutions. Finally, as many as $92 \%$ of the involved citizens found it exciting to participate in the Task Committees and were willing to do it again.

Politicians also evaluated the outcomes of the Task Committees positively: $54 \%$ of them agreed that the Task Committees had fostered a constructive and crosscutting dialogue that they had learned a lot from participating in, and $60 \%$ agreed that the Task Committees had given them a better understanding of the problems and challenges at hand. Moreover, $53 \%$ of the politicians agreed that participation had given them new inputs and ideas, and $48 \%$ agreed that the Task Committees had contributed to the development of new and better solutions that would not have been developed in the Standing Committees or in the City Council meetings alone. Only $25 \%$ disagreed with this statement. The interviews provide several examples of how the collaboration between politicians and citizens led to innovative policy solutions such as integrated job and language training for refugees, the promotion of a local sharing economy, and the use of nudging strategies to enhance traffic safety. Lastly, but significantly, $75 \%$ of the politicians agreed that the Task Committees had enabled citizens to contribute more actively to the implementation of new and bold policy solutions. In sum, with very few exceptions, they all agreed that collaborative interaction in the new Task Committees had enhanced the local councilors' political leadership.

The administrators were even more positive than the politicians with regard to the Task Committees' capacity to produce policy innovation: $77 \%$ of them agreed that the Task Committees had contributed to the development of new and better solutions. Yet, our interviews with the administrators also revealed a clear limit to the innovativeness of the new solutions. One of them claimed that: 'We could easily have designed most of policy solutions that are developed in the Task Committees in the administration'. However, she continued: 'Policy solutions have a much higher legitimacy when they are developed in the Task Committees and sometimes the policies are actually quite innovative'. Hence, judging from these accounts, it is the combination of innovation and legitimacy that is the real contribution of the interactive political leadership that is exercised in and through the Task Committees. However, the municipal director added another important point:

'I hear both politicians and citizens saying that the quality of the political solutions has improved and that there is now a shorter distance from idea to action. For example, the politicians claim that they could never have developed the new Youth Policy without the close interaction with the local youth. (...) Moreover, some of the youngster from the Task Committee have been touring around the municipality to present the new youth policy to other young people. This means that the new policy is already being implemented even before the administration has come up with an implementation plan'.

Hence, to innovation and legitimacy we can add the speedy implementation of new policies. Accelerated implementation may, in the final instance, compensate for the extra time spent on policy formulation in the collaborative arenas.

Our analysis reveals considerable variation in the functioning of the Standing Committees, but the general impression is that the shift from case processing to strategic monitoring has been difficult and that the reduced number of meetings makes it difficult to find time for political discussions that allow for passion and disagreement. The many complaints about the limited time for political discussion indicate that administrative case processing still takes up too much time and thus that the transition to strategic oversight 
is not yet complete. The need for further adjustment of the work of the Standing Committees is confirmed by the survey, which shows that $60 \%$ of the politicians disagree with the statement that the Standing Committees are functioning well with their current focus and meetings schedule.

In addition to having more time for political discussion, the councilors would like to spend more time giving feedback on the oral interim reports they receive from the Task Committees. It is crucial for the councilors to influence the direction of the policy deliberations in the Task Committees before the new policy proposals are set in stone and become too difficult to change, even for the City Council. As such, it was suggested to us that the Standing Committees should discuss the interim reports from the Task Committees in a joint meeting in order to provide valuable political feedback.

The meetings in the City Council are still marred by antagonistic clashes between the conservative mayor and an adamantly left-wing council member. The initial worry that there would be an explosion of single-issue cases and budgetary discussions in the City Council, now that there was no longer room for these in the Standing Committees, has proven to be unsubstantiated. On the positive side, there is a general agreement amongst the politicians that the collective knowledge base in the City Council has been strengthened because the councilors bring new information and knowledge from the Task Committees into play in the council meetings. On the negative side, the local councilors claim that it is difficult to find a good way to discuss the proposals that the Task Committees have developed and delivered to the City Council. Most of the proposals have already been politically vetted in the process of multi-actor collaboration, but politicians who are critical of the new policy proposals find it hard to speak against them in front of the citizens. Hence, there is a risk that elected politicians may be taken hostage by the Task Committees if they have not had sufficient sway over the policy process in the Task Committees. Despite this problem, 59\% of the local councilors agreed that the Task Committees had strengthened the City Council's ability to solve important policy problems.

In sum, the Task Committees appear to work well and contribute to enhancing the political leadership of the elected councilors by involving them in sustained interaction with citizens and local stakeholders that helps to provide valuable inputs to understanding local policy problems, generating new ideas and stimulating mutual learning in the solutions phase, building joint ownership over new and bold solutions, and accelerating implementation. Perhaps most importantly, the policy deliberations in the Task Committees have spurred collaborative policy innovation and enhanced the legitimacy of local policymaking. By contrast, the Standing Committees have not yet found their feet and seem to be in the midst of a learning process where their traditional focus on administrative case processing sits uneasily wrestles with their new strategic monitoring role. Finally, the City Council must find a new way to evaluate and influence the policy process in the Task Committees, either directly by providing political feedback on mid-term reports, or indirectly through the Standing Committee members of the different Task Committees.

\section{Discussion}

The Gentofte Model provides a concrete example of how local councilors can enhance their political leadership through institutional reform of their political working conditions. The relative success of the Gentofte model has generated considerable interest from other municipalities and there are several examples of adoption, adaptation and reinvention of the Gentofte Model both in Denmark and Norway. 
In the Danish context, the institutional reforms in Gentofte are pretty exceptional. The municipal amalgamation reform in 2007 prompted many Danish municipalities to strengthen political communication with local citizens and enhance the use of traditional forms of citizen participation through consultations, hearings and town-hall meeting. About half of all Danish municipalities have established one or more thematic ad hoc committees that resemble the Task Committees (these are referred to as $\S 17.4$ Committees in the Local Government Act). However, only Gentofte Municipality has aspired to make thematic ad hoc committees with citizen participation an integral part of its political governance model, and created a permanent platform for the formation of interactive policy arenas. Hence, in the Danish context, Gentofte Municipality constitutes 'best practice' when it comes to building interactive political leadership; especially after the second round of Task Committees has solved some of the beginner's errors.

The Gentofte Model shows that co-creation of public policy with citizens and local stakeholders is not merely a tool that public managers can use to mobilize local resources in the field of service production (Osborne, Radnor and Strokosch, 2016), but also offers a means for elected politicians to strengthen their political leadership by developing new policy solutions with broad ownership. Politicians all over Europe seem eager to engage local citizens and stakeholders more actively, but this rarely happens in such a systematic and integrated way as in Gentofte. What makes the Gentofte Model stand out in an international context is that politicians do not merely receive an external input from deliberative citizens' juries, but instead work closely together with citizens and relevant stakeholders to develop new policies and make joint policy recommendations to the City Council. This example may offer new inspiration to other experiments with bottom-up policy deliberation such as the G1000 in Belgium and the Netherlands and the ubiquitous use of participatory budgeting.

The new interactive Task Committees are the centerpiece of the Gentofte Model. Nevertheless, what is particularly interesting is that collaborative policy development both begins and ends in the City Council that not only forms and mandates the Task Committees, but also discusses, amends and adopts the policy proposals resulting from sustained dialogue with civil society actors. As such, the primacy of politics and the possibility to hold councilors to account for policymaking on election-day is preserved. The combination of executive decisionmaking and deliberative policymaking makes the Gentofte Model resemble the strategic planning model found in for-profit and non-profit organizations (Bryson, 2011). Strategic planning processes involve thinking, learning and acting, and tend to have strong elements of participation and deliberation. According to the strategic planning model, public leaders must first identify problems, create a vision for the future and define overall objectives. They may then use specific mandates to instruct and empower actors in participatory and deliberative arenas to reflect on the formulation of problems and objectives, develop creative strategies through processes of mutual learning and turn these strategies into concrete plans that will eventually achieve the desired strategic objectives. Finally, they may use their own organization and the assistance they can get from the participating actors to implement the new plans. This is more or less how the process of issue-specific policy development is conducted in Gentofte.

A strategic planning model similar to the Gentofte Model has been developed at some universities, where the bicameral governance model has been replaced by a new model combining strategic leadership with participatory and deliberative arenas (Jarzabkowski, 2008; Delbecq, Bryson and Van de Ven, 2013). Evaluations of these new forms of university governance arrive at similar conclusions as our study of the 
Gentofte Model. The new institutional design helps to build trust and enhance input and output legitimacy and on these grounds it has been recommended to other universities.

The successful design, implementation and outcomes of the Gentofte Model beg the question of the scope conditions for enhancing interactive political leadership. There is no point in hiding the highly favorable conditions for the emergence of the Gentofte Model, notably three important country-specific conditions. In Denmark, the unique combination of a strong and well-functioning state with a low level of corruption and a strong and well-organized civil society with plenty of social capital has generated a longstanding tradition for public-private collaboration in formalized corporatist systems at the national level, and for more informal forms of co-creation at the local level. In addition, there is a high degree of devolution of public tasks to the local municipalities, which dispose of two thirds of the public budget. As such, Danish municipalities deliver the majority of public welfare services and social transfer payments to citizens, and they also provide local infrastructure, regulation and support for culture, business and leisure activities, partly financed by municipal taxes. As such, they both have the formal competences and the economic resources to make an impact on the lives of local citizens and the interests of local stakeholders, making it both important and worthwhile for them to participate in local decisionmaking arenas and attempt to influence the political decisions taken by local government. Last but not least, there is a long tradition for collaborative responses to crises that goes back to the cooperative movement that helped Danish farmers to make the shift from crops to livestock farming when the new railroads brought cheap wheat from Russia to Europe in the 1870s. Later, the cooperative movement enabled the workers movement to mitigate the dislocating effects of rapid industrialization. The idea of collaborating to overcome crisis and dislocation has been an integral part of the Danish DNA ever since.

There also some local case-specific factors supporting the development of the Gentofte model. Gentofte is a rich and well-managed municipality and that helps to create room for risk-taking reforms that might not have seen the light of day in a municipality with economic and managerial problems. By global comparison, Gentofte Municipality is relatively small in terms of number of inhabitants and geographical size. Distances are small, so nobody would have to travel more than 15-20 minutes to participate in a meeting in the City Hall. Moreover, an above average educational and income level in the local population, with many academics who have experience with collaborative problem-solving from their work life tends to facilitate empowered participation in collaborative policy innovation. A final factor is the presence of a stable political majority that means that the mayor controls all the decisions taken in the City Council. However, while the stable majority clearly mitigates the political risks of co-created policymaking, it also begs the question of why the mayor wants to share his power with the other councilors and local citizens and stakeholders. The answer might be that interactive political leadership tends to enhance overall political governing capacity, and through that the power and reputation of the mayor (who increased his party's electoral support by 8 percentage points in the local election in November 2017). The mobilization of local resources and the creation of a higher degree of input and output legitimacy enable the municipality to do things it could not otherwise have done, and the political leader is likely to benefit from that.

\section{Conclusion and ways ahead}


This paper has identified an unfortunate mismatch between the urgent need for stronger democratic political leadership in the face of the complex problems confronting European societies and the rather unfavorable conditions for exercising political leadership. The way out of this impasse is to exploit the recent surge in interactive forms of governance and the emergence of a more active, empowered and assertive citizenry in developing a new form of interactive political leadership in which citizens and relevant stakeholders become an active resource for elected politicians who are seeking to define pressing policy problems and design and implement new and innovative policy solutions in ways that work on the ground.

The development of interactive political leadership finds theoretical support in the recent rapprochement between governance research and political leadership theory, which may provide an initial foundation for theory building. However, the advancement of a comprehensive theory of interactive political leadership, including insights into how it is conditioned by the design of platforms and arenas and how it may spur the production of innovative policy solutions, is hampered by the lack of empirical studies. Our empirical analysis of the Gentofte Model is a first step towards filling this gap. Our explorative case study revealed an ambitious and relatively successful attempt to transform working conditions for elected councilors in a medium-sized Danish municipality which now serves as a beacon for other Danish (and some Norwegian) municipalities. What is particularly remarkable about the Gentofte Model is the way that it combines political agenda-setting and democratic accountability on the part of the City Council with flexible use of institutional platforms and arenas for collaborative policymaking. Hence, the Gentofte Model introduces a new kind of hybrid democracy by integrating elements of participatory and deliberative democracy into the classical model of representative democracy. What works really well is to bring together elected politicians and a team of carefully selected citizens and private stakeholders to discuss pressing problems and policy ambitions and work together to design new and creative solutions that are subsequently adopted by the City Council.

Hopefully, the Gentofte Model is only the beginning of a broader attempt to rethink political leadership in the age of interactive governance. Empirical studies of other, similar cases are required in order to determine the generic features of interactive political leadership and to begin to catalogue and categorize different subspecies. Comparative case studies will also be helpful in developing a general understanding of the competing constellations of factors that allow interactive political leadership to emerge and thrive. At the theoretical level, the strategic planning model needs further development in order to capture efforts by elected politicians to mobilize citizens' knowledge, ideas and resources and enhance collaborative policy innovation. Finally, there is an urgent need to study the changing role perceptions of the elected politicians, public administrators and citizens who are involved in interactive political leadership. The old roles and the traditional division of labor between these key actors are disrupted by the new practices, and it is not yet clear what the new roles and forms of interaction will entail. 


\section{References}

Ansell, C. and Gash, A. (2017), 'Collaborative platforms as a governance strategy', Journal of Public Administration Research and Theory, 28(1): 16-32.

Ansell, C. K. and Torfing, J. (Eds) (2014), Public Innovation through Collaboration and Design, London: Routledge.

Ansell, C. K. and Torfing, J. (Eds) (2016), Handbook on Theories of Governance, Cheltenham: Edward Elgar.

Ansell, C. K. and Torfing, J. (2017), 'Strengthening political leadership and policy innovation through the expansion of collaborative forms of governance', Public Management Review, 19(1): 37-54.

Ansell, C. K., Trondal, J. and Øgård, M. (Eds) (2017), Governance in Turbulent Times, Oxford: Oxford University Press.

Beetham, D. (2011), 'Do Parliaments have a Future?', in S. Alonso, J. Keane, and W. Merkel (Eds), The Future of Representative Democracy, Cambridge, Cambridge University Press, 24-43.

Bommert, B. (2010), 'Collaborative innovation in the public sector', International Public Management Review, 11(1): 15-33.

Bryson, J. M. (2011), Strategic Planning for Public and Nonprofit Organizations, New York: John Wiley.

Burns, J. M. (2003), Transformative Leadership, New York, NY: Grove Press.

Caluwaerts, D. and Reuchamps, M. (2015), 'Strengthening democracy through bottom-up deliberation: An assessment of the internal legitimacy of the G1000 project', Acta Politica, 50(2): 151-170.

City Hall, (2015), Ny Politisk Arbejdsform Tættere på Borgerne, Gentofte: Gentofte Municipality.

Considine, M., Lewis, J. M. and Alexander, D. (2009), Networks, Innovation and Public Policy, Basingstoke: Palgrave-Macmillan.

Crosby, B. C. and Bryson, J. M. (2005), Leadership for the Common Good: Tackling Public Problems in a SharedPower World). John Wiley \& Sons.

Dalton, R. (2007), 'Partisan mobilization, cognitive mobilization and the changing American electorate', Electoral Studies, 26(2): 274-286.

Dalton, R. J. and Welzel, C. (Eds) (2014), The Civic Culture Transformed: From Allegiant to Assertive Citizens, Cambridge: Cambridge University Press.

Delbecq, A. L., Bryson, J. M. and Van de Ven, A. H. (2013), 'University governance: Lessons from an innovative design for collaboration', Journal of Management Inquiry, 22(4): 382-392.

Emerson, K., Nabatchi, T. and Balogh, S. (2012), 'An integrative framework for collaborative governance', Journal of Public Administration Research and Theory, 22(1): 1-29. 
Ercan, S. A. (2014), 'Same problem, different solutions', in A. K. Gill, C. Strange and K. Roberts (Eds), Honor Killing and Violence, Basingstoke: Palgrave Macmillan, pp. 199-217.

Fung, A. and Wright, E. O. (Eds) (2003), Deepening Democracy: Institutional Innovations in Empowered Participatory Governance, London: Verso.

Gray, B. (1989), Collaborating: Finding Common Ground for Multiparty Problems, San Francisco, CA: JosseyBass.

Hamilton, A., Madison, J., Jay, J., and Fairfield, R. P. (1966 [1787]), The Federalist Papers, Baltimore: Johns Hopkins University Press.

Hartley, J., Sørensen, E. and Torfing, J. (2013), 'Collaborative innovation: A viable alternative to market competition and organizational entrepreneurship', Public Administration Review, 73(6): 821-830.

Helms, L. (2012a), 'Democratic political leadership on the new media age', The British Journal of Politics and International Relations, 14(4): 651-670.

Helms, L. (Ed.) (2012b), Poor Leadership and Bad Governance, Cheltenham: Edward: Elgar.

Helms, L. (2014), 'Institutional Analysis', in R. A. W. Rhodes, and P. 't Hart (Eds), The Oxford Handbook of Political Leadership, Oxford: Oxford University Press, 195-209.

Hendriks, C. M. (2013), Elected Representatives and Democratic Innovation, Canberra: Crawford School of Public Policy.

Hood, C. (2011), The Blame Game: Spin, Bureaucracy, and self-preservation in Government, Princeton, Princeton University Press.

Hoodge, L. and Marks, G. (2002), Multi-level Governance and European Integration, Lanham: Rowman and Littlefield.

Jarzabkowski, P. (2008), 'Shaping strategy as a structuration process', Academy of Management Journal, 51(4): 621-650.

Jessop, B. (2002), The Future of the Capitalist State, Cambridge: Polity Press.

Kane, J., Papatan, H. and 't Hart, P. (2009), 'Dispersed Democratic Leadership Revisited', in Kane, J., H. Patapan, H. and 't Hart, P. (Eds), Dispersed Democratic Leadership: Orgins, Dynamics, and Implications, Oxford: Oxford University Press, pp. 299-321.

Kickert, W., Klijn, E.-H. and Koppenjan, J. (Eds) (1997), Managing Complex Networks, London: Sage.

Kingdon, J. W. (1984), Agendas, Alternatives, and Public Policies, Boston: Little Brown.

Kjær, U. and Opstrup, N. (2016), Variationer I udvalgsstyret, Copenhagen: Local Government Denmark.

Klijn, E.-H. (2014), 'Political leadership in networks', in R. A. W. Rhodes and P. 't Hart (Eds), The Oxford Handbook of Political Leadership, Oxford: Oxford University Press, pp. 403-418. 
Koppenjan, J., Kars, M. and Voort, H. van der (2011), 'Politicians as metagovernors', in Torfing, J. and Triantafillou, P. (Eds), Interactive Policy Making, Metagovernance and Democracy, Colchester: ECPR Press, pp. 129-148.

Koppenjan, J. and Klijn, E.-H. (2004), Managing Uncertainties in Complex Networks, London: Routledge.

Krause, R. M. (2011), 'Policy innovation, intergovernmental relations, and the adoption of climate protection initiatives by US cities', Journal of Urban Affairs, 33(1): 45-60.

Lees-Marshment, J. (2015), The Ministry of Public Input, Basingstoke: Palgrave-Macmillan.

Light, P. C. (2015), 'Vision + action $=$ faithful execution', Issue Paper, https://www.volckeralliance.org/sites/default/files/attachments/Vision\%20\%2B\%20Action\%20-

\%20The\%20Volcker\%20Alliance.pdf., Retrieved on August 28, 2016.

Lijphart, A. (1999), Patterns of Democracy, New Haven: Yale University Press.

Marsh, D. and Rhodes, R. A. W. (Eds) (1992), Policy Networks in British Government, Oxford: Oxford University Press.

Masciulli, J., Molchanov, M. and Knight, A. W. (2009), 'Political leadership in context', in Masciulli, J., Molchanov, M. and Knight, A. W. (Eds), The Ashgate Research Companion to Political Leadership, pp. 3-27.

Norris, P. (2011), Democratic Deficit: Critical Citizens Revisited, Cambridge: Cambridge University Press.

Nye, J. S. (2008), The Power to Lead, Oxford: Oxford University Press.

OECD (2013), Government at a Glance 2013, OECD: OECD Publishing.

Olsen, J. P. (1978), 'Folkestyre, byråkrati og korporatisme', in Olsen, J. P. (Ed.), Politisk organisering, Oslo: Oslo University Press, pp. 15-114.

Osborne, S. P., Radnor, Z. and Strokosch, K. (2016), 'Co-Production and the Co-Creation of Value in Public Services: A suitable case for treatment?', Public Management Review, 18(5): 639-653.

Page, E. C. (2012), Policy without Politicians, Oxford: Oxford University Press.

Polsby, N. W. (1984), Political Innovation in America, New Haven: Yale University Press.

Post, J. M. (2014), 'Personality profiling analysis', in R.A.W Rhodes, and P. 't Hart (Eds), The Oxford Handbook of Political Leadership, London: Oxford University Press, pp. 328-346.

Rhodes, R. A. W. (1997), Understanding Governance: Policy Networks, Governance, Reflexivity and Accountability, Milton Keynes: Open University Press.

Richardson, J. (2000), 'Government, interest groups and policy change', Political Studies, 48(5): 1006-1025.

Roberts, N. C. (2000), 'Wicked problems and network approaches to resolution', International Public Management Review, 1(1):1-19. 
Rosanvallon, P. (2011), Democratic Legitimacy, Princeton: Princeton University Press.

Sirianni, C. (2009), Investing in Democracy: Engaging Citizens in Collaborative Governance, Washington, D.C.: The Brookings Institute Press.

Smith, G. (2009), Democratic innovations: Designing Institutions for Citizen Participation, Cambridge University Press.

Stoker, G. (2006), 'Politics in mass democracies: destined to disappoint?', Representation, 42(3): 181-194.

Strøm, K. (1998), 'Parliamentary committees in European democracies', Journal of Legislative Studies, 4(1): 21-59.

Sørensen, E. (2006), 'Metagovernance: The changing role of politicians in processes of democratic governance', The American Review of Public Administration, 36(1): 98-114.

Sørensen, E. (2017), 'Political innovations: Innovations in political institutions, processes and outputs', Public Management Review, 19(1): 1-19.

Sørensen, E. (2018), Interactive Political Leadership, Oxford: Oxford University Press, Forthcoming.

Sørensen, E. and Torfing, J. (2005), 'The democratic anchorage of governance networks', Scandinavian Political Studies, 28(3): 195-218.

Sørensen, E. and Torfing, J. (Eds) (2007), Theories of Democratic Network Governance, Basingstoke: Palgrave Macmillan.

Sørensen, E. and Torfing, J. (2009), 'Enhancing effective and democratic network governance through metagovernance', Public Administration, 87(2): 234-258.

Sørensen, E. and Torfing, J. (2011), 'Enhancing Collaborative Innovation in the Public Sector', Administration and Society, 43(8): 842-868.

Sørensen, E. and Torfing, J. (2015), 'Beskrivelse af formål med og indhold af den nye politiske arbejds- og organisationsform', Delrapport 1, Gentofte: Gentofte Municipality, 2nd of December 2015.

Sørensen, E. and Torfing, J. (2016a), 'Political leadership in the age of interactive governance: Reflections on the political aspects of metagovernance', in J. Edelenbos and Meerkerk, I. F. (Eds), Critical Reflections on Interactive Governance, Cheltenham: Edward Elgar, pp. 444-466.

Sørensen, E. and Torfing, J. (2016b), 'Samlet evaluering af den nye politiske arbejdsform i Gentofte kommune', Delrapport 4, Gentofte; Gentofte Municipality, 22nd of November 2016.

Torfing, J. (2016), Collaborative Innovation in the Public Sector, Washington, DC: Georgetown University Press.

Torfing, J. (2018), 'Collaborative innovation in the public sector: The argument', Public Management Review, forthcoming. 
Torfing, J., Peters, B. G., Pierre, J. and Sørensen, E. (2012), Interactive Governance: Advancing the Paradigm, Oxford: Oxford University Press.

Tucker, R. C. (1995), Politics as Leadership, Columbia: University of Missouri Press.

Walter, J. (2014), 'Biographical analysis', in R. A. W. Rhodes, and P. 't Hart (Eds), The Oxford Handbook of Political Leadership, Oxford: Oxford University Press, 314-327.

Weber, M. (2009 [1948]), From Max Weber: Essays in Sociology, London: Routledge. 